\title{
HUBUNGAN POLA ASUH DEMOKRATIS DAN KECENDERUNGAN PERILAKU AGRESIF DENGAN MOTIVASI BERPRESTASI PADA SISWA KELAS XI IPS SMAN 91 JAKARTA TIMUR
}

\author{
Abdur Rohman', Andri Kosala', Nessa Hamdani ${ }^{3}$ \\ Email : abdurrohman.psikologi@gmail.com ${ }^{1}$, \\ Fakultas Magister Psikologi Universitas Persada Indonesia YAI ${ }^{1,2,3}$
}

\begin{abstract}
Abstrak.
Indonesia saat ini sedang mengalami krisis dalam bidang nilai dan moral pada generasi remaja, khususnya pada lingkungan sekolah. Lingkungan yang tidak mendukung dan pola asuh yang buruk dapat berkontribusi pada penurunan motivasi berprestasi di sekolah. Penurunan motivasi berprestasi yang ditinjau dari fenomena ini adalah hal menarik. Penelitian dengan judul "Hubungan Pola Asuh demokratis dan Kecenderungan Perilaku Agresif dengan Motivasi Berprestasi pada Siswa Kelas XI IPS Jakarta Timur”, memiliki rumusan masalah apakah ada hubungan antara pola asuh demokratis terhadap motivasi berprestasi, kecenderungan perilaku agresif terhadap motivasi, serta pola asuh demokratis dan kecenderungan perilaku agresif terhadap motivasi berprestasi siswa kelas XI IPS SMAN 91 di Jakarta Timur. Tujuan dari penelitian ini adalah untuk mengetahui hubungan ketiga variable dan mengetahui seberapa besar hubungannya. Penelitian ini menggunakan metode angket dengan menggunakan skala Likert. Adapun sumber data yang digunakan adalah skala motivasi berprestasi, skala pola asuh demokratis, dan skala kecenderungan perilaku agresif. Data akan dianalisa dengan metode korelasi ganda. Berdasarkan analisis data yang dilakukan maka dapat disimpulkan bahwa terdapat hubungan yang kuat dan signifikan antara pola asuh demokratis dan kecenderungan perilaku agresif tehadap motivasi berprestasi. Saran penelitian ini adalah guru hendaknya meningkatkan kompetensi dalam mempertahankan motivasi siswa
\end{abstract}

Kata kunci : Motivasi Berprestasi, Pola Asuh, Agresivitas

\section{PENDAHULUAN}

Kehidupan adalah hal yang mutlak harus dihadapi oleh setiap individu, baik yang berbentuk kesenangan maupun kesulitan. Setiap individu memang harus siap menghadapi berbagai masalah yang dihadapi. Bagi individu yang tidak menyadari akan hakikat dari hidup ini akan menganggap masalah sebagai beban bahkan dapat menghambat potensi yang dimilikinya. Hal tersebut mendorong beberapa individu untuk lebih menonjolkan eksistensinya dengan eksplorasi yang berlebihan untuk mencari perhatian lingkungan sekitar.

$$
\text { Indonesia saat ini sedang }
$$
mengalami krisis dalam bidang nilai dan moral pada generasi remaja, khususnya pada lingkungan sekolah. Hal tersebut seperti berkurangnya nilai, norma, dan keyakinan yang dimiliki oleh setiap anggota masyarakat. Hal ini mengakibatkan tidak adanya ikatan masyarakat dengan aturan-aturan moral yang telah menjadi kesepakatan bersama. Remaja saat ini sudah terlalu mengikuti budaya barat yang tidak terkontrol dan meliputi pergaulan bebas, tawuran, dan mencoba challenge yang membahayakan seperti skip challenge. Siswa indonesia dalam hal ini perlu belajar bagaimana menggunakan dan mengontrol potensi yang dimilikinya secara optimal untuk mengambil keputusan terhadap masalah 
bukan hanya mementingkan moral namun juga tidak merugikan individu lain.

Masa-masa remaja adalah masa ketika individu mencoba untuk mencari jati diri mereka. Individu remaja biasanya akan bersikap secara aktif dan bergelora untuk mengekspresikan jati diri mereka terhadap lingkungan. Hal ini sebagai implikasi dari peralihan perkembangan psikisnya. Remaja saat ini dapat melakukan berbagai aktifitas yang cenderung negative bahkan tidak memandang usia dan tempat bersekolah, tidak terkecuali sekolah elit yang ada kemungkinan kegiatan negatif diluar sekolah. Dalam hal ini, sikap agresi yang dilakukan remaja terkait salah satunya dengan pergaulan bebas. Hal tersebut memuaskan rasa ingin tahu mereka terhadap hal-hal baru. Hal ini yang membuat terkadang remaja melakukan aktifitas yang diluar kontrol. Remaja cenderung untuk melakukan konformitas terhadap kelompoknya.

Hal tersebut menunjukkan bahwa masa remaja adalah masa yang paling banyak dipengaruhi oleh lingkungan dan teman-teman sebaya. Implikasi tersebut dilatarbelakangi oleh pertubahan tingkat emosional yang belum stabil. Individu remaja belum cukup mampu dalam memfilter pengaruh yang didapat dari teman sebaya. Dalam hal ini remaja gemar membolos dan menentang kedua orangtua karena mementingkan kepentingan kelompok sebagai perwujudan dari sikap toleransi yang dimilikinya. Hal tersebut tentu mempengaruhi prestasi di sekolah terutama dengan adanya sikap agresi dan minat berkuasa di lingkungan sekolah. Untuk itu, diharapkan individu remaja dapat memiliki kecerdasan emosional agar dapat berperilaku sesuai dengan nilai dan moral. Dalam hal ini remaja biasa melakukan kegiatan mereka di sekolah.

Sekolah adalah tempat untuk membentuk karakter dan potensi individu. Sekolah memberi fasilitas yang dapat mengembangkan rasa ingin tahu individu. Selain itu, sekolah juga dijadikan individu sebagai tempat untuk berkomunikasi terhadap sesamanya. Biasanya individu akan membentuk suatu kelompok belajar yang dapat menunjang prestasi di sekolah. Tidak jarang, individu-individu dalam kelompok tersebut memiliki pertentangan ide antara satu individu dengan individu yang lain untuk menciptakan suatu inovasi. Hal tersebut adalah sebagai implikasi dari pemenuhan kebutuhan yang tinggi dan usaha kontribusi individu terhadap kelompoknya. Dengan demikian, dapat menimbulkan kecenderungan persaingan antar sesama individu.

Selain itu, iklim dan pengalaman belajar di kelas juga menimbulkan 
kecenderungan persaingan. Setiap individu merasa terpacu dengan persaingan tersebut dan menciptakan motivasi yang tinggi. Begitu pun sebaliknya. Hal tersebut mendorong setiap individu untuk mengatur strategi dalam proses pembelajaran. Dalam hal ini diperlukan tingkat kedewasaan pada individu remaja dalam menghadapi permasalahan yang ada termasuk persaingan tersebut sehingga mempengaruhi motivasi dalam berprestasi.

Menurut Santrock (2014, p. 165), motivasi berprestasi adalah pengunggahan kualitas diri dan bertujuan untuk mencapai kesuksesan. Motivasi berprestasi juga dapat membuat stabil emosional dan mengarahkannya kepada hal yang positif serta memiliki ekspektasi yang pasti. Hal tersebut tentunya sangat memberikan keuntungan kepada individu yang dapat teguh pada prinsip dan komitmen sendiri karena memungkinkan individu tersebut untuk berpikir secara divergen meskipun fasilitas yang disediakan kurang mendukung. Individu dalam hal ini akan memiliki eksistensi yang tinggi sebagai implikasi dari prestasinya tersebut.

Berdasarkan penjelasan Santrock tersebut, bahwa setiap individu terkadang memiliki kecemasan yang membuat individu tersebut tidak stabil emosionalnya. Ketidakstabilan emosi ini menimbulkan beberapa kesenjangan yang termasuk diantaranya adalah kesenjangan prestasi di sekolah. Kesenjangan ini biasanya akan terus terjadi berkelanjutan jika tidak segera dicari pemecahan masalahnya. Hal yang sangat berperan dalam terjadinya kecemasan dalam hal ini adalah pola asuh orangtua karena setiap individu memang belajar sikap dan tingkah laku dari lingkungan terdekat sehingga pola asuh dapat mempengaruhi motivasi berprestasi. Kecemasan tersebut dapat diminimalisasi salah satunya dengan “mencapai kesuksesan".

Pola asuh orang tua adalah bentuk sosialisasi dan komunikasi nilai serta moral yang diterapkan pada anak dimana anak akan belajar tentang sikap, tingkah laku serta etika dalam bermasyarakat (Monks, et al, 2007). Penerimaan pola asuh oleh anak dapat berkembang menjadi motivasi berprestasi jika pola asuh yang diterapkan orangtua tidak mengekang anak. Pola asuh seperti ini akan meningkatkan kepercayaan diri individu. Individu dalam hal ini akan mendapatkan bimbingan untuk menghadapi rintangan dan mempertahankan prestasinya. Individu juga dapat membentuk sikap disiplin dari pola asuh yang dipelajari anak sehingga dapat meningkatkan motivasi. 
Lingkungan yang tidak mendukung pemenuhan kebutuhan dasar individu, dalam hal ini pola asuh yang buruk dapat menghambat kestabilan emosi dan pengambilan keputusan dalam diri individu. Pola asuh yang buruk tersebut salah satunya adalah sikap agresi yang berlebihan dari orangtua terhadap anaknya baik fisik maupun verbal. Hal tersebut dapat mempengaruhi penyesuaian individu terhadap lingkungan diluar keluarga, termasuk sikap agresi dari teman sebaya. Individu yang mengalami kecemasan dan ketakutan dari pola asuh orantuanya cenderung akan menarik diri atapun melakukan sikap yang sama dengan sikap orangtuanya. Hal tersebut dapat mempengaruhi motivasi berprestasi individu. Maka, pola asuh adalah moderator dalam hubungan antara sikap agresi teman sebaya dan motivasi berprestasi.

Secara umum individu yang menanamkan motivasi berprestasi yang tinggi akan stabil, selain dalam mengelola emosi juga dalam menghadapi persaingan. Akan tetapi hal tersebut dapat menjadi tidak stabil karena kurangnya kontrol untuk mengekspresikan diri. Hal ini dipengaruhi oleh berbagai hal, termasuk diantaranya adalah kecenderungan perilaku agresif. Hal inilah yang menyebabkan kecenderungan perilaku agresif menjadi perhatian publik. Pada dasarnya remaja yang memiliki kondisi emosional yang tidak stabil dan tidak terkontrol akan menimbulkan kecenderungan perilaku agresif. Ketegangan emosi tinggi, membuat suasana belajar tidak kondusif. Sehingga kecenderungan perilaku agresif yang tinggi dari lingkungan dapat membuat motivasi berprestasi menurun.

$$
\text { Rodriguez (2004, p. 434) }
$$
berpendapat bahwa kecenderungan perilaku agresif yang dilakukan remaja menunjukkan keinginnannya akan kebutuhan kekuatan, penerimaan sosial, dan individuasi oleh teman sebayanya. Individu akan menunjukkan perilaku ini dapat dengan cara menunjukkan dominansinya pada kegiatan sekolah. Hal ini juga dapat dilakukan dengan cara mengejek, menuding, bahkan dengan kekerasan. Agresi memiliki kecenderungan sangat tinggi untuk mengarahkan individu kepada perilaku negatif serta meningkatkan kecemasan dan stress (Sullivan, 2004, p. 642). Maka dapat disimpulkan bahwa individu yang memiliki kecenderungan perilaku agresif belum tentu dapat menarik perhatian dari teman sebaya dan belum tentu juga kebutuhan individu tersebut terpenuhi.

Masalah umum terkait kebutuhan yang dialami inidividu tersebut akan 
menimbulkan perhatian lebih besar dari guru dan konselor pendidikan yang memang bertugas mengawasi individu seperti mereka. Karena pada dasarnya individu yang lebih meningkatkan perilaku agresif akan merugikan dirinya sendiri juga orang lain. Individu akan memiliki lebih banyak pengalaman terkait masalah tersebut dan dapat lebih dapat merenungkan tujuan dari agresifitas yang dilakukannya. Jika individu tersebut menyadari bahwa kecenderungan perilaku agresif yang dilakukan bersifat positif, dalam arti sedikit berdampak pada diri sendiri dan lingkungan maka individu akan berhasil memenuhi kebutuhannya akan prestasi. Maka dapat disimpulkan bahwa kecenderungan perilaku agresif dapat dikontrol untuk mempengaruhi motivasi berprestasi di sekolah.

Sebagai akibat dari kebutuhan yang semakin meningkat, khususnya kebutuhan berprestasi, individu remaja akan mengalami lebih banyak ketegangan emosional di sekolah dan dalam hubungan dengan teman sebaya. Hal ini akan membuat individu ingin menunjukkan kepopulerannya dengan berbagai macam cara yang bersifat positif atupun negatif. Jika individu memilih cara negatif, artinya individu tersebut lebih menekankan pada kecenderungan perilaku agresif pada proses belajarnya. Sehingga gambaran mengenai prestasi sangat relatif dan hal tersebut juga dapat berpengaruh terhadap motivasi berprestasinya.

Hal tersebut kurang lebih sama dengan kondisi pada siswa-siswi terutama siswa kelas XI IPS SMAN 91 Jakarta Timur, dapat dikatakan bahwa remaja di SMA ini terlihat memiliki perilaku agresi yang cukup mempengaruhi motivasi belajar. Hal ini ditunjukkan dengan sering mengobrol ketika guru sedang menjelaskan, sering pulang ketika belum waktunya pulang dan membuat guru marah. Bahkan, ada satu individu remaja yang melakukan pemerasan terhadap teman sebayanya.

Tentunya kondisi seperti itu sangat memprihatinkan mengingat remaja adalah penerus bangsa, terlebih lagi perilaku agresi yang bdilakukan mereka tentu akan berpengaruh terhadap prestasi. Oleh karena itu, remaja masih sangat membutuhkan bimbingan dan pengarahan supaya dapat mengambil langkah yang tepat sesuai dengan kondisinya serta dapat menjadi pribadi yang berkualitas.

\section{KAJIAN PUSTAKA}

\section{Motivasi Berprestasi}

Menurut Santrock (2014, p. 165), motivasi berprestasi adalah pengunggahan kualitas diri dan bertujuan untuk mencapai kesuksesan. Hal tersebut biasanya ditandai 
dengan semangat yang bergelora serta pola belajar yang efektif dan efisien. Individu yang berada pada iklim kelas dinamis biasanya memiliki motivasi yang tinggi. Hal ini disebabkan oleh persaingan dalam proses belajar yang membutuhkan banyak energy dan kesiapan mental. Hal tersebut ditambah dengan kondisi keluarganya termasuk keharmonisan hubungannya pada keluarga. Oleh karena itu perlu adanya bimbingan belajar yang dapat membuat individu termotivasi.

Menurut McClelland (dalam Reksohadiprojo \& Handoko, 1996, p. 85) Individu dengan motivasi berprestasi yang tinggi mampu memenuhi beberapa kebutuhan berikut, diantaranya

Kebutuhan Prestasi

Individu biasanya menampilkan hasil yang lebih baik pada tugas-tugas yang dilakukan, cenderung mengambil risiko yang wajar dan diperhitungkan, serta Mencermati lingkungan untuk mencari peluang. Hal tersebut dilandasi oleh motivasi sekunder yang dimiliki individu. Individu tidak akan mudah menyerah dalam mencapai suatu kesuksesan maupun dalam berkompetisi.

Kebutuhan afiliasi

Kebutuhan ini dilandasi oleh motivasi primer. Individu ini akan bergaul untuk memperoleh pengalaman, mencoba memperoleh umpan balik dari perbuatanya. Hal ini memuaskan rasa ingin tahu dan menimbulkan rasa aman. Kebutuhan ini juga mendukung kebutuhan prestasi untuk meningkatkan proses belajar. Individu akan mampu menggali potensi mereka sendiri.

Kebutuhan Mendominansi

Individu akan peka terhadap pengaruh antar pribadi dan mencoba menguasai orang lain dengan mengatur perilakunya dan membuat orang lain terkesan kepadanya. Hal ini membantunya dalam mempertahankan hubungan interpersonal yang berperan dalam proses pembelajaran. Individdu yang memiliki motivasi yang tinggi akan dapat mengontrol kebutuhan ini agar tidak berlebihan.

Carol Dweck (dalam Santrock (2014, p. 176 - 177) menyebutkan beberapa hal yang dapat mempengaruhi motivasi seseorang diantaranya : 1) penguasaan orientasi, motivasi dapat dipengaruhi oleh strategi dan pola belajar, ambisi serta semangat juga dapat memberikan pengaruh terhadap motivasi berprestasi individu, 2) orientasi performa, apabila individu percaya mampu memperhatikan proses belajar maka individu tersebut akan termotivasi untuk melakukan upgrade sehingga berpengaruh dalam bertingkah laku, 3) pola pikir prestasi yang tinggi biasanya diidentikkan 
dengan optimis karena hal itu terkait dengan pola asuh orangtua dan konsep belajar sosial.

\section{Pola Asuh Demokratis}

Conny Semiawan (2002, p. 57 58) mendefinisikan pola asuh sebagai suatu hubungan orangtua dan anak yang mempunyai aspek moral dan suasana kondusif. Pola asuh menjadikan seseorang mampu berperilaku seperti yang dibutuhkan untuk memperoleh hasil yang diharapkan. Disini terlihat bahwa adanya penekanan kepercayaan diri yang tinggi dari hasil pola asuh. Pola asuh juga menghasilkan suatu kepuasan individu mengenai dirinya sendiri dan rasa puas terhadap apa yang dilakukan. Dalam hal tersebut, kecerdasan emosional memegang peranan yang lebih besar dalam keberhasilan dalam mengelola sikap dan kesuksesan seseorang dalam berprestasi. Karena kecerdasan emosional mampu menjadi sarana internalisasi nilai dan moral.

Menurut John Amos Comenius (2015), prinsip pola asuh adalah memenuhi kebutuhan dasar anak, diantaranya sebagai berikut: Kebutuhan biologis, diantaranya seperti makanan bergizi, air dan udara bersih, serta istirahat yang cukup. Kebutuhan ini sangat penting untuk memuaskan pemenuhan motivasi primer. Kebutuhan keamanan, termasuk rasa kasih sayang orangtua terhadap anak. Hal ini penting untuk menjaga kestabilan emosi anak. Aspek tersebut berfungsi untuk mempertahakan sikap baik pada saat remaja. Hal ini juga berperan dalam meningkatkan motivasi. Kebutuhan intelektual dan stimulasi, berkaitan dengan masa perkembangan remaja yang mengalami banyak perubahan baik secara fisik, psikis, dan sosial, menyebabkan remaja merasa ragu-ragu dan canggung terhadap perannya. Dengan pemenuhan kebutuhan ini, remaja dapat belajar untuk mengambil keputusan. Hal ini karena adanya pandangan orangtua atau orang dewasa lainnya bahwa remaja mampu mengatasi masalahnya sendiri dengan pengarahan dari orangtua sehingga hal ini akan tergantung pada pola asuh yang diterapkan. Kebutuhan moral spiritual. Kurang terpenuhinya kebutuhan ini menyebabkan kurangnya rasa percaya diri pada remaja berkaitan dengan tuntutan sosial di luar diri remaja. Tuntutan lingkungan yang selalu menekankan remaja untuk berprestasi akademik yang tinggi akan dapat menimbulkan perasaan kurang berhasil pada diri, sehingga dapat menghambat kepercayaan dirinya. Selain itu, remaja juga senantiasa dituntut untuk dapat menyesuaikan diri dengan suasana baru dan berbagai konflik yang ada serta membuat keputusan yang tepat dalam 
hidupnya. Oleh karena itu, internalisasi pola asuh memegang peranan penting dalam pembentukan karakter.

Individu yang berperilaku baik tentunya tidak akan lepas dari pengaruh pola asuh orangtua. Bronfrenbrenner (dalam Lestari, 2012, p. 39 - 41) secara tidak langsung memaparkan ciri-ciri pola asuh jika dipandang dari perspektif ekologis, antara lain:

- Pola asuh macrosystem yang terkait dengan beradaptasi di lingkungan masyarakat. Hal ini melatih anak untuk belajar bertanggung jawab terhadap keputusan yang dibuat dan mampu menyadari kesalahan yang diperbuat. Hal ini juga yang terkadang membuat orangtua memaksakan anaknya untuk berpretasi.

- Pola asuh mesosystem yang terkait dengan koodinasi orangtua terhadap keberhasilan anak dalam proses belajar. Kehadiran orangtua dalam hal ini penting untuk meningkatkan rasa percaya diri anak sehingga anak mudah menyesuikan diri dan mempertahankan prestasi.

- Pola asuh microsystem yang terkait dengan sosialisasi nilai. Dengan pola asuh, individu memiliki pegangan hidup yang kuat dan mampu mengembangkan motivasi. Individu belajar dari nasihat serta pengalaman.
- Pola asuh chronosystem yang terkait dengan trend pengasuhan. Hal tersebut juga terkait dengan budaya worckaholic serta akan berpengaruh pada pola pikir.

Pola asuh demokratis menjadi pola asuh yang efektif untuk membentuk karakter anak. Tridhonanto menyebutkan bahwa ada beberapa aspek yang diperlukan dalam pola asuh demokrasi (2014, p. 44 - 47) antara lain sebagai berikut: 1) Kedisiplinan, yaitu sikap yang dimiliki individu untuk menghormati dan menghargai serta mentaati peraturan. Selain itu Individu yang disiplin juga dapat membentuk pengendalian dan pengarahan diri. Hal ini penting untuk memahami diri sendiri demi mencari pola pemecahan masalah yang tepat. Kedisiplinan menjadi salah satu factor yang meningkatkan kematangan emosional. Dalam hal motivasi, individu dapat mengelola waktu dengan efektif, 2) Kebersamaan, merupakan aspek dalam masyarakat yang terdiri dari menghormati dan menghargai setiap individu, kerja sama, dan sikap tidak menyinggung orang lain. Hal ini terkait dengan adanya rasa empati yang dimiliki individu. Dengan menjaga kebersamaan dalam keluarga, anak belajar untuk peduli terhadap orang lain sehingga individu memiliki rasa tanggung jawab sosial yang tinggi. Hal 
tersebut dapat menjadi acuan untuk beradaptasi dengan lingkungan. 3) Gotong royong, aspek ini termasuk dalam kebersamaan. Gotong royong mengacu pada kemampuan untuk membina hubungan interpersonal dengan memelihara tenggang rasa dan saling peduli. Sehingga Individu dapat mengelola emosi diri dan mengenali perbedaan. Dengan ini maka perilakunya dapat terkendali dan emosinya memberi makna yang lebih baik.

\section{Kecenderungan Perilaku Agresif}

Sawitri Supardi Sadarjoen (2005, p. 146 - 152) mengemukakan bahwa agresi adalah perilaku yang berlandaskan pada penghayatan rasa frustasi akibat tidak terpenuhinya kebutuhan. Perilaku agresi terjadi karena individu tidak dapat mengontrol kemarahannya dan hambatan yang sulit diselesaikan. ia juga mengemukakan tentang adanya repressed aggression yang merupakan serangakaian sikap menghayati kecemasan. Represi akan menimbulkan sikap waspada yang dapat menghindarkan individu dari bahaya jika tidak waspada berlebihan. Perilaku agresi ektrem dapat merugikan atau melukai.individu lain.

Agresi merupakan suatu perilaku yang tidak semua bersifat negative. Ada beberapa perilaku agresi yang tidak berbahaya, seperti yang disebutkan oleh
Erich Fromm (2004, p. 362 - 365) membagi tipe agresivitas menjadi empat kelompok yaitu:

- Accidental aggression, yaitu tindakan menyakiti, mengganggu, atau membahayakan orang lain melalui ketidaksengajaan.

- Playful aggression, yaitu tindakan agresi untuk melatih keterampilan tertentu.

- Self-assertive aggression, merupakan suatu bentuk reaksi afektif berupa dorongan fisiologis sebagai tahap persiapan dari pengarahan perilaku. Beberapa aspek agresi seperti marah, kesal, dan sebal dikontrol dalam rangka proses pencapaian prestasi. Hal tersebut dipengaruhi oleh harapan setiap individu

- Defensive aggression, yaitu tergolong kedalam agresi instrumental. Agresi mewakili kekhawatiran terhadap suatu ancaman. Dalam hal ini agresi bersifat adaptif dimana individu mempunyai caranya masing-masing untuk melakukan agresinya.

Barbara Krahe (2005, p. 90 - 95) mengatakan bahwa ada beberapa aspek dalam kecenderungan perilaku agresif yang pengaruhnya sangat vital bagi diri individu yang melakukan, diantaranya: (1) Iritabilitas yang merupakan kecenderungan impulsive. Individu ini 
akan cepat melakukan tindakan agresi karena memiliki ketegangan yang tidak menyenangkan seperti dalam hal marah, iri, benci, tidak menurut, dan sebagainya;

\section{(2) Kerentanan emosional dimana} terdapat gejala-gejala negativisme seperti putus asa. Individu yang kerentanan emosinya tinggi akan memperkuat perilaku agresi; (3) Dissipation (pikiran yang kacau) dan rumination (perenungan). Ruminator yang tinggi menyebabkan pengalihan agresi yang positif. Sebaliknya, jika dissipator yang tinggi maka akan memperkuat agresi; Dan (4) Gaya atribusional permusuhan. Individu yang memiliki bias atribusi permusuhan cenderung memiliki perspektif disposisi kognitif yang rendah sehingga mengutamakan agresi sebagai solusi. Keempat hal tersebut pada akhirnya berkaitan dengan control diri yang menyebabkan perilaku agresi setiap individu berbeda.

Sedangkan menurut Baron dan Byrne (2005, p. 140-141), karakteristik perilaku agresif diantaranya sebagai berikut:

\section{- Agresi fisik}

Perilaku yang dimaksudkan seperti agresi fisik terhadap individu lain dan barang. Individu yang menunjukan kecenderungan perilaku ini biasanya mengalami masalah emosi atau perilaku. Individu dengan kecenderungan perilaku agresif fisik akan mendapatkan masalah tambahan seperti tidak diterima oleh teman-temannya dan dianggap sebagai pembuat masalah oleh guru. Kecenderungan perilaku agresif akan diperkuat dengan penguatan status dari lingkungan, seperti dianggap hebat oleh teman sebaya, atau didapatkannya sesuatu yang diinginkan, termasuk melihat temannya menangis saat dipukul olehnya.

\section{- Agresi verbal}

Perilaku agresi verbal sendiri mencakup tindakan seperti membantah, memaki, mengeluh dan mengumpat, serta penghinaan dan kebohongan. Hal ini menunjukkan adanya superioritas secara verbal dan adanya gejala negativisme. Individu perlu belajar untuk menghargai orang lain agar perilaku agresi verbal tidak terjadi. Untuk itu, individu harus membentuk self-esteem agar tidak ada gejala negativisme.

\section{- Agresi pasif}

Perilaku agresi ini diantaranya menolak bicara dan tidak menjawab pertanyaan. Hal ini dilatarbelakangi oleh emosi seperti mood dan juga oleh sikap apati.

Sylvia Rymm (1997, p. 156 - 157) mengemukakan 4 faktor utama, antara lain: (1) Korban dan tayangan kekerasan. Hal ini merupakan salah satu faktor yang paling sering menjadi penyebab perilaku agresi. Perilaku agresi dilandasi oleh rasa 
ingin tahu sehingga anak akan mudah meniru perilaku agresi tersebut. (2) Terlalu dimanjakan adalah sikap orangtua yang salah karena menumbuhkan perilaku manipulative pada anak sehingga meningkatkan agresi yang dilakukan oleh orang lain. Apalagi jika orangtua membela kesalahan anak maka akan menumbuhkan sikap egois pada anak. (3) Kemarahan. Pada umumnya orang akan berperilaku agresi terhadap provokasi secara langsung. Hal ini dapat juga ditimbulkan dari penelantaran orangtua. (4) Penyakit. Frustrasi terjadi bila seseorang tidak bisa mencapai suatu tujuan. Hal ini yang membuat perilaku agresi muncul. Penyakit dan ketidakberdayaan adalah salah satu penyebabnya.

\section{METODOLOGI PENELITIAN}

Populasi dalam penelitian ini adalah seluruh siswa dan siswi SMA kelas XI IPS SMAN 91 di Jakarta Timur yang berjumlah 3 kelas sebanyak 108 siswa, sedangkan responden yang digunakan sebagai sampel berdasarkan table Morgan yaitu sebesar 80 responden.

Pengumpulan data dilakukan dengan menyebarkan kuesioner yang berdasarkan skala Likert terhadap para responden. Kuesioner terdiri dari 3 variabel, yaitu: 1) Variabel motivasi berprestasi 27 item pertanyaan, 2)
Variabel pola asuh demokratis dengan 25 item, 3) Dan variabel kecenderungan perilaku agresif dengan 24 item

\section{HASIL DAN PEMBAHASAN}

Teknik analisis data dalam penelitian ini menggunakan SPSS untuk pengujian kuesioner yaitu uji validitas dan reliabilitas serta uji hipotesis. Uji validitas dilakukan dengan melihat nilai alpha chronbach yang dibandingkan dengan total alpha dari setiap faktor pada 3 variabel yang diteliti, hasil menunjukkan bahwa pada skala motivasi berprestasi yang berjumlah 27 butir terdapat 7 aitem yang tidak valid dan jumlah 20 butir valid, pada skala pola asuh demokratis yang berjumlah 25 hanya gugur 2 butir, serta skala kecenderungan perilaku agresif yang berjumlah 24 hanya valid 19 butir. Sedangkan untuk Uji Reliabilitas menggunakan nilai alpha chronbach dan berdasarkan kaidah Guilford. Hasil menunjukkan bahwa instrumen motivasi berprestasi memiliki Alpha Cronbach sebesar 0,645 (reliabel), instrumen pola asuh demokratis memiliki Alpha Cronbach sebesar 0,833 (sangat reliabel), sedangkan instrumen kecenderungan perilaku agresi memiliki Alpha Cronbach sebesar 0,684 (reliabel).

Pengujian hipotesis dilakukan dengan menggunakan metode Multiple Correlation pada ketiga variabel. Hasil 
dari pengujian ini antara lain, hipotesis 1 yang menyatakan bahwa ada hubungan antara pola asuh demokratis terhadap motivasi berprestasi menghasilkan $r$ sebesar 0,631 (hubungan yang kuat) dengan $\mathrm{p}$ sebesar 0.000 dimana $\mathrm{p}<0.05$, hipotesis 2 yang menyatakan bahwa ada hubungan antara kecenderungan perilaku agresif terhadap motivasi berprestasi menghasilkan $r \quad$ sebesar $\quad((-0,443)$ Hubungan yang cukup kuat) dengan $\mathrm{p}$ sebesar 0.000 dimana $\mathrm{p}<0.05$, dan hipotesis 3 yang menyatakan bahwa ada hubungan antara pola asuh demokratis dan kecenderungan perilaku agresif terhadap motivasi berprestasi menghasilkan $\mathrm{R}$ sebesar 0,641 dengan $\mathrm{P}$ sebesar 0,000 yangmana $\mathrm{p}<0.05$ sehingga $(\mathrm{H} 0)$ ditolak dan (Ha) diterima yang menyatakan bahwa "Ada hubungan antara kecenderungan perilaku agresi dan pola asuh demokratis dengan motivasi berprestasi siswa kelas XI IPS SMAN 91 di Jakarta Timur".

Hal tersebut merupakan bukti bahwa semakin baik pola asuh yang diterapkan orangtua semakin baik juga motivasi berprestasi namun perilaku agresif perlu dikontrol agar tidak menurunkan motivasi berprestasi, karena menurut Carol Dweck (dalam Santrock (2014, p. 176 - 177)) pola asuh dalam hal ini pola asuh demokratis berkaitan dengan konsep belajar social sedangkan menurut Sawitri Supardi Sadarjoen (2005, p. 146 152), agresi adalah perilaku yang berlandaskan pada penghayatan rasa frustasi akibat tidak terpenuhinya kebutuhan, dalam hal ini Individu tidak dapat mengalihkan rasa frustasinya danterjadilah perilaku agresi sehingga membuat lingkungan belajar tidak kondusif. Hal inilah yang menyebabkan penurunan motivasi berprestasi.

\section{PENUTUP}

\section{Kesimpulan}

Ada hubungan antara pola asuh demokratis terhadap motivasi berprestasi siswa kelas XI IPS SMAN 91 di Jakarta Timur. Hal tersebut membuktikan bahwa pola asuh demokratis sangat berperan penting dalam peningkatan motivasi. Oleh karena itu pola asuh demokratis efektif jika diberikan sejak usia dini.

$$
\text { Ada hubungan antara }
$$
kecenderungan perilaku agresif dengan motivasi berprestasi siswa kelas XI IPS SMAN 91 di Jakarta Timur. Berdasarkan hasil yang sudah dijelaskan sebelumnya maka perlu diperhatikan aspek kecenderungan perilaku agresif agar stabil sehingga tidak menurunkan motivasi berprestasi.

$$
\text { Ada hubungan antara }
$$

kecenderungan perilaku agresi dan pola asuh demokratis dengan motivasi 
berprestasi siswa kelas XI IPS SMAN 91

di Jakarta Timur. Hal ini dibuktikan selain dengan nilai signifikansi yang sama anatara ketiga variabel juga sikap mengulur waktu siswa untuk masuk kedalam kelas. Hubungan ketiga variabel merupakan bukti dari pola asuh yang kurang efektif sehingga dapat mempengaruhi tingkat motivasi berprestasi.

\section{Saran}

Secara teoretis, dengan adanya penelitian ini diharapkan agar bermanfaat bagi pengembangan ilmu pengetahuan, khususnya pada psikologi sosial dan psikologi pendidikan, dapat menambah wawasan bagi para pembaca, juga sebagai referensi yang berguna bagi penelitianpenelitian lain yang mempunyai relevansi dengan penelitian ini.

Perilaku agresif dan pola asuh adalah dua aspek yang vital jika salah mengambil sikap. Oleh karena itu, orangtua sebaiknya terbuka dengan pikiran dan permasalahan anak agar dapat mengambil keputusan yang benar. Sedangkan guru disarankan memiliki kompetensi lebih untuk menangani siswa dengan perilaku agresif.

\section{DAFTAR PUSTAKA}

Anantasari. 2006. Menyikapi Perilaku Agresif Anak. Yogyakarta: Kanisius
Azwar, S. 2004. Metode Penelitian. Yogyakarta: Pustaka Belajar

Azwar, S. 2005. Tes Prestasi: Fungsi dan Pengembangan Pengukuran Prestasi Belajar. Yogyakarta: Pustaka Belajar

Baron, R. G. \& Byrne, D. 2005. Psikologi Sosial. Jakarta: Erlangga

Blokland, E. A. W. D., Engels, R. C. M. E., \& Finkenauer, C. 2001. Parentingstyles, self control and male juvenile delinquency. Dalam M. Martinez (Ed), Prevention and control of aggression and the impact on its victims (pp. 201). Newyork: Kluwer Academic.

Chourmain, M. A. S. I. 2008. Acuan Normatif Penelitian Untuk Penulisan Skripsi, Tesis, dan Disertasi. Jakarta: Al-HaramainPublishing House

Dimyati \& Mudjiono. n.d.. Belajar dan Pembelajaran. Jakarta: Rineka Cipta

Fromm, E. 2004. Masyarakat Bebas Agresivitas. Maumere: Ledalero

Goldstein, S. E., Young, A., \& Boyd, C. 2008. Relational Aggressional at School: Association with school safety and social climate [Versi elektronik]. Journal Youth Adolscence, 37, 641-654.

Hamalik, O. 2003. Proses Belajar Mengajar. Bandung: Bumi Aksara

Handoko, M. 1992. Motivasi Daya Penggerak Tingkah Laku. Yogyakarta: Kanisius

Handoko, H. \& Reksohadiprodjo, S. 1996. Organisasi Perusahaan. Yogyakarta: BPFE

Hardre, P. L., Sullivan, D. W., \& Crowson, H. M. 2009. Student 
Characteristics and Motivation in Rural High School [Versi elektronik]. Journal Research in Rural Education, 24(16), 1-19

Harefa, A. 2000. Menjadi Manusia Pembelajar. Jakarta: Kompas

Kerlinger, F. N. 2004. Asas-asas Penelitian Behavioral. Yogyakarta: Gadjah Mada University Press

Krahe, B. 2005. Perilaku Agresif. Yogyakarta: Balai Pustaka

Lestari, S. 2012. Psikologi Keluarga. Jakarta: Kencana

Lopez, E. E., Perez, E. M., Ochoa, G. M., \& Ruiz, D. M. 2008. Adolscence Aggression: Effects of gender and family and school environment [Versi elektronik]. Journal of Adolscence, 31, 433-350.

Megawangi, R. 2010. Membangun Karakter Anak melalui Brain-based Parenting. Depok: Indonesia Heritage Foundation

Nawawi, H. 2007. Metode Penelitian Bidang Sosial. Yogyakarta: Gadjah Mada University Press

Purwanto, Y. \& Mulyono, R. 2006. Psikologi Marah: Perspektif Psikologi Islami. Bandung: Refika Aditama

Rymm, S. 1997. Mendidik dan Menerapkan Disiplin pada Anak Prasekolah. Jakarta: Gramedia

Sadarjoen, S. S. 2005. Jiwa yang Rentan: Pernak-pernik Permasalahan Kepribadian, Kejiwaan, dan Stress. Jakarta: Kompas
Santrock, J. W. 2014. Psikologi Pendidikan. Jakarta: Salemba Humanika

Santrock, J. W. 2007. Psikologi Remaja. Jakarta: Erlangga

Sardiman, A. M. 2012. Interaksi dan Motivasi Belajar Mengajar. Jakarta: Grafindo

Sarwono, S. W. 2002. Psikologi Sosial: Individu dan Teori-Teori Psikologi Sosial. Jakarta: Balai Pustaka

Schunk, D. H., Pintrich, P. R., \& Meece, J. L. 2002. Motivation in Education: Theory, Research, and applications. New Jersey: Pearson International Education

Semiawan, C. 2002. Pembangunan keluarga dalam era global. Jakarta: Prenhallindo IKAPI

Semmelroth, C. 2005. The Anger Habit in Parenting: Terapi Menghilangkan Kebiasaan Marah kepada Anak. Bandung: Kaifa

Shochib, M. 1998. Pola Asuh Orangtua dalam Membantu Anak Mengembangkan Disiplin. Jakarta: Rineka Cipta

Suciati. 2015. Psikologi Komunikasi: Sebuah Tinjauan Teoritis dan Perspektif Islam. Yogyakarta: Buku Litera

Sukmadinata, N. S. 2005. Landasan Psikologi Proses Pendidikan. Bandung: Remaja Rosdakarya

Sulastri, U. 2015. Golden Touch Parenting. Jakarta: Adi Bintang IKAPI 
Surna, I. N. 2015. Pengembangan Diri. Jakarta: Fakultas Psikologi UPI YAI

Surya, H. 2009. Menjadi Manusia Pembelajar. Jakarta: Kompas

Suryabrata, S. 2003. Psikologi Kepribadian. Jakarta: Grafindo

Tridhonanto, A. 2014. Mengembangkan Pola Asuh Demokratis. Jakarta: Kompas

http://agresivitaspsikologi.blogspot.co.id/2 014/12/agresivitas_23.html

http://anaksholehaqiqah.blogspot.co.id/20 15/03/prinsip-pola-asuh.html

https://id.wikipedia.org/wiki/Perilaku_ma nusia

http://kbbi.web.id/cenderung. 